\title{
An evaluation of the ToxHA test for the detection of antibodies to Toxoplasma gondii in human serum
}

\author{
ALAN H BALFOUR, JOHN B BRIDGES, AND JOHN P HARFORD
}

From the Toxoplasma Reference Laboratory, Regional Public Health Laboratory, Bridle Path, York Road. Leeds LSI5 7TR, UK

SUMMARY The titre of antibodies to Toxoplasma gondii was compared in 1985 sera by use of an indirect haemagglutination test (ToxHA test-Wellcome Reagents Ltd) and the dye test. Sera from 42 patients with clinical or serological indications of recent toxoplasmosis were also examined to determine if the ToxHA test would be of value in detecting early stages of the disease. Nine recent cases of lymphadenopathy and four cases of eye infection were not detected by the test. In addition, a large number of sera found negative in the dye test gave a positive result in the haemagglutination test.

The method of choice in diagnosing an infection due to Toxoplasma gondii is by the detection of specific antibodies against the parasite in the patient's serum. ${ }^{1}$ The dye test of Sabin and Feldman, ${ }^{2}$ subsequently modified, ${ }^{3} 4$ is still regarded as the definitive test in the diagnosis of toxoplasmosis.

Although specific, sensitive, and reproducible, ${ }^{5}$ the dye test is technically difficult and slow, requiring the use of live parasites and suitable human serum as a source of 'accessory factor'. This has led to a search for less exacting but equally effective techniques.

The indirect haemagglutination test (IHAT) of Jacobs and Lunde $^{6}$ and its modifications ${ }^{7-9}$ is a potential alternative to the dye test. A test kit is now commercially available which detects antibodies against $T$. gondii by the agglutination of sensitised turkey cells (ToxHA test-Wellcome Reagents Ltd).

In order to evaluate this test for routine use, we have compared results in the ToxHA test and dye test using 1985 sera routinely submitted to us. In addition, we have examined 42 sera chosen from patients where the available serological and clinical evidence suggested a toxoplasma infection of recent origin, to determine the performance of the ToxHA test in detection of these early cases.

\section{Material and methods}

A total of 1985 sera, submitted to the Regional Public Health Laboratory at Leeds for routine toxoplasma serology, were initially examined. On

Received for publication 1 November 1979 receipt they were heat inactivated $(56 \mathrm{C}$ for 30 minutes) and stored at $4{ }^{\circ} \mathrm{C}$ for up to two days with any further storage at $-20^{\circ} \mathrm{C}$. A further 42 sera selected from cases with a strong indication of recent infection, including (i) a fourfold or greater rise in titre in the dye test, (ii) a specific IgM titre $>1 / 16$. or (iii) a dye test titre $>1 / 128$ with a haemagglutination test titre $₹ 1 / 256,{ }^{9}$ were examined to determine the value of the ToxHA test in detecting such cases.

METHYLENE-BLUE DYE TEST

The dye test was performed lising the method of Beverley and Beattie, ${ }^{3}$ a modification of the original Sabin ard Feldman method. ${ }^{2}$

TOXHA TEST

The Wellcome ToxHA test is an indirect haemagglutination test utilising turkey erythrocytes sensitised with an ultrasonicate of $T$. gondii. In the presence of specific antibody, agglutination of the red cells is produced. The test is supplied freeze dried, in kit form, together with control cells, positive and negative control sera, and buffered diluent.

Reagents were rehydrated according to the manufacturers' instructions and the test was carried out in $\mathrm{V}$-shaped microtitre plates. Serum samples of $25 \mu \mathrm{l}$ were picked up using a Compu-pet 100 diluter/ dispenser (William R Warner \& Co Ltd, Eastleigh, SO5 3ZQ) and delivered to the appropriate well in column 1 of the plate together with $75 \mu \mathrm{l}$ of diluent to give an initial 1/4 dilution. After column 1 had been loaded with sera, further dilutions were prepared across the plate using an 8-channel microCompu-pet multidiluter (WR Warner \& Co) set to 644 
pick up $25 \mu \mathrm{l}$ and deliver a total volume of $100 \mu \mathrm{l}$ at each step, leaving a final volume of $75 \mu \mathrm{l}$ in each well. Dilutions of $1 / 64,1 / 256,1 / 1024$, and $1 / 4096$ were prepared as tests for each serum, and $25 \mu \mathrm{l}$ of the sensitised turkey red cells was added to each using a Micro-re/pettor (Alpha Laboratories, 45 Ruislip Road, Greenford, Middlesex UB6 9QD). A further pickup of $25 \mu \mathrm{l}$ was made from the $1 / 16$ column and used to deliver a 1/64 serum dilution for use as controls, a $25 \mu \mathrm{l}$ aliquot of unsensitised cells being added to each. Positive and negative sera as well as antigen controls were included with each batch of sera. After shaking, the plates were left for 1-2 hours at room temperature and the agglutination pattern was determined. The las: well showing complete agglutination was taken as the endpoint; whenever non-specific agglutination was observed, the serum was absorbed with unsensitised turkey red cells and re-titrated. Test cell batch K5661/1 was used throughout this study.

\section{OTHER SEROLOGICAL TESTS}

The indirect haemagglutination test (IHAT) and the indirect immunofluorescence test for IgM antibodies (IgM-IFAT) were performed using the methods described by Karim and Ludlam. ${ }^{9}$ All anomalous results were checked by retesting.

\section{STANDARDISATION}

The Toxoplasma National Control serum, produced at the Public Health Laboratory, St George's Hospital, Blackshaw Road, London SW17 OQT, was used as a reference serum. This serum has been standardised against the WHO International Control Serum, issued by the State Serum Institute, DK-2300, Copenhagen S, Denmark.

\section{Results}

A total of 1985 sera, submitted for routine toxoplasma serology, were examined in the initial study, and titres in the ToxHA test and dye test were compared. The results are shown in Table 1. Non-

Table 1 Examination of routinely submitted human sera by the ToxHA and dye tests

\begin{tabular}{rrrrrrr}
\hline Dye test & \multicolumn{2}{l}{ ToxHA test } & & & Totals \\
\cline { 2 - 5 } & \multicolumn{1}{c}{$<64$} & 64 & 256 & 1024 & $\$ 4096$ & \\
\hline$<16$ & 900 & 319 & 130 & 25 & 12 & 1386 \\
16 & 23 & 118 & 76 & 5 & 3 & 225 \\
64 & 4 & 60 & 104 & 16 & 1 & 185 \\
256 & 0 & 8 & 67 & 32 & 4 & 111 \\
1024 & 1 & 4 & 18 & 11 & 6 & 40 \\
4096 & 2 & 2 & 4 & 10 & 9 & 27 \\
16000 & 0 & 1 & 3 & 2 & 1 & 7 \\
\$16 000 & 0 & 0 & 1 & 0 & 1 & 2 \\
Totals & 930 & 512 & 403 & 101 & 37 & 1983 \\
\hline
\end{tabular}

specific reactions with unsensitised red cells were found with 38 sera $(1.9 \%)$. Two of these sera, with dye test titres of $1 / 64$ and $1 / 16$, still showed nonspecific reactions to a titre of $1 / 64$ after absorption and have been excluded from Table 1. Taking a titre of $>1 / 64$ as indicating a positive result in both the dye test and the ToxHA test, the relative distribution of positive and negative sera between the two tests was as shown in Table 2. The ToxHA test detected $98.1 \%(365 / 372)$ of the dye test positive sera but also gave positive results for $42.7 \%(688 / 1611)$ of the sera found negative by the dye test. A total of $1072 / 1983(54 \%)$ of the sera gave the same titre in both tests.

A total of seven sera were positive in the dye test but negative in the ToxHA test (Table 3). Lymphadenopathy associated with a high dye test titre and suggesting a recent infection occurred with three of these sera. A low dye test titre $(1 / 64)$ was associated with a fourth case of lymphadenopathy, suggesting a previous rather than current $T$. gondii infection.

Table 2 Distribution of positive ard negative sera detected by the dye test and ToxHA test (1983 sera)

\begin{tabular}{llcr}
\hline Dye test & ToxHA test & & Total \\
\cline { 2 - 3 } & Positive & Negative & \\
\hline Positive & 365 & 7 & 372 \\
Negative & 688 & 923 & 1611 \\
\hline
\end{tabular}

Table 3 Dye test positive sera not detected by the ToxHA test $(<1 / 64)$

\begin{tabular}{|c|c|c|c|}
\hline $\begin{array}{l}\text { Dye test } \\
\text { titre }\end{array}$ & $\begin{array}{l}\text { No. } \\
\text { sera }\end{array}$ & Clinical symptoms & Comments \\
\hline \multirow[t]{2}{*}{$1 / 64$} & 1 & Lymphadenopathy & $\begin{array}{l}\text { Significance } \\
\text { doubtful }\end{array}$ \\
\hline & 1 & Uveitis & Evidence of a \\
\hline \multirow[t]{2}{*}{$1 / 128$} & 1 & Uveitis & previous \\
\hline & 1 & Choroiditis & $\begin{array}{l}\text { infection } \\
\text { which may } \\
\text { have caused } \\
\text { the eye } \\
\text { damage }\end{array}$ \\
\hline $1 / 1024$ & 1 & Lymphadenopathy (7 mth) & Consistent \\
\hline $1 / 4096$ & 1 & Lymphadenopathy (5-6 wk) & with an \\
\hline $1 / 8192$ & 1 & Lymphadenopathy (5-6 wk) & $\begin{array}{l}\text { active infec- } \\
\text { tion }\end{array}$ \\
\hline
\end{tabular}

There were three eye infections in this group of sera. Eye damage is often not apparent until long after the initial infection and is associated with low levels of residual antibody.

Further evidence on the value of the ToxHA test in detecting early infections was sought by examining sera from 42 selected patients meeting the serological criteria listed in Table 4, together with clinical symptoms suggestive of a recent infection. The ToxHA test failed to detect specific antibody in 
seven cases $(16.7 \%)$ giving a titre of $<1 / 64$. Of these sera, six were from patients presenting with lymphadenopathy of not more than three months' duration, while the remaining serum was from a patient later found to have a long-standing choroiditis.

Table 4 Examination by the ToxHA test of sera from 42 patients with a recent toxoplasma infection

\begin{tabular}{llll}
\hline $\begin{array}{l}\text { Criteria for a 'recent } \\
\text { infection' }\end{array}$ & $\begin{array}{l}\text { No. of } \\
\text { patients }\end{array}$ & $\begin{array}{l}\text { ToxHA } \\
<1 / 64\end{array}$ & $\begin{array}{l}\text { Clinical symptoms in } \\
\text { ToxH } 1 \text {-ve sera } \\
\text { patients }\end{array}$ \\
\hline $\begin{array}{l}\text { Rising dye test titre } \\
\text { Dye test }>1 / 128, \\
\text { plus }\end{array}$ & 5 & 21 & $\begin{array}{l}\text { Lymphadenopathy } \\
\text { Lymphadenopathy }\end{array}$ \\
$\begin{array}{l}\text { IgM-IFAT }>1 / 16 \\
\text { Dye test }>1 / 128,\end{array}$ & 16 & 3 & 1 \\
$\begin{array}{l}\text { IHAT } ₹ 1 / 256 \\
\text { Total }\end{array}$ & 42 & 1 & $\begin{array}{l}\text { Lymphadenopathy } \\
\text { Choroiditis }\end{array}$ \\
\hline
\end{tabular}

\section{Discussion}

Haemagglutination tests for $T$. gondii are normally prepared using soluble antigenic components of the parasite, while in the dye test viable intact organisms are used. In the course of an infection, exposure of the host's immune system to intact parasites will precede exposure to cellular contents. Previous workers have shown that the antibody response, measured in these two tests, differs. ${ }^{6} 1011$ Karim and Ludlam $^{9}$ were able to demonstrate that in glandular toxoplasmosis antibody levels, measured in their haemagglutination system, rose more slowly than those measured by the dye test. In the present study, nine cases diagnosed as glandular toxoplasmosis and all showing evidence of being recent infections, were not detected by the ToxHA test commercially supplied.

The ToxHA test also gave titres of $<1 / 64$ in four cases of eye infection in which significant levels of antibody were detected by the dye test. In the IHA test used by Karim and Ludlam ${ }^{9}$ antibody levels were shown to persist at similar, or slightly higher, levels than those detected by the dye test in longstanding infections.

A problem with the ToxHA test demonstrated in this study is the large number of sera showing positive and even high titres in this test but low or negative titres in the reference test, the dye test. The ToxHA test demonstrated in 167 sera $(8.4 \%)$ a titre of $>1 / 256$ and in a further 319 sera $(16 \cdot 1 \%)$ a titre of $1 / 64$, all associated with a dye test titre of $<1 / 16$. The total number of sera with a dye test $<1 / 64$ and a positive ToxHA result was $688(34 \cdot 7 \%)$.

Complete agglutination was used to determine end points in this study, rather than a $50 \%$ end point as recommended by the kit manufacturers, but if this end point had been used even higher titres would have been expected in the ToxHA test. While this might have helped in detecting some of the earlier cases it would also have resulted in more sera showing positive ToxHA titres and a negative dye test.

The ToxHA titres are all specific in that reaction with unsensitised cells has been excluded but high ToxHA titres and negative dye test titres suggest that at least some of this specificity must be directed against non-toxoplasma constituents of the antigenic material used in the red cell sensitisation. As the parasite is grown in the mouse, the non-toxoplasma antigenic constituents could possibly be of mouse origin. The detection of antibodies against this material can be of only doubtful diagnostic significance.

The use of paired sera to test for a fourfold rise in titre should remove some of the uncertainty in interpretation of ToxHA test results, but further clarification of immunity of $T$. gondii requires the use of a second test, preferably one measuring antibody against cell wall component. ${ }^{9} \mathrm{~A}$ single production batch of sensitised cells was used throughout this study, and variations in the level of false positives and undetected early infections between batches could not be determined. Standardisation, with good reproducibility between batches, is claimed by the manufacturers. The ToxHA test, an indirect haemagglutination test for the detection of specific antibodies to $T$. gondii, is relatively simple to perform, and end points can be readily determined. The test is designed for use in the microtitre system, lending itself to mechanisation. The rehydrated test cells have a limited storage life which may be a disadvantage for the smaller laboratory where only occasional sera are examined. The indirect haemagglutination test system has many advantages for the smaller laboratory with limited equipment and the larger laboratory because of the possibilities of mechanisation. However, the ToxHA test needs modification to reduce the level of false positive results, but, at the same time, the sensitivity for the detection of early cases needs to be improved.

Identification and isolation of the antigenic components of $T$. gondii. eliciting the earlier immune response as measured in the dye test, should allow the development of an indirect haemagglutination test more closely aligned to the dye test.

We are grateful to Wellcome Reagents Ltd for kindly supplying the ToxHA materials used in this study. 


\section{References}

${ }^{1}$ Anderson SE, Remington JS. The diagnosis of toxoplasmosis. South Med J 1975;68:1433-43.

2 Sabin AB, Feldman HA. Dyes as microchemical indicators of a new immunity phenomenon affecting a protozoon parasite (toxoplasma). Science 1948; 108:660-3.

${ }^{3}$ Beverley JKA, Beattie CP. Standardisation of the dye test for toxoplasmosis. J Clin Pathol 1952;5: 350-3.

${ }^{4}$ Frenkel JK, Jacobs L. Ocular toxoplasmosis: pathogenesis, diagnosis, and treatment. Arch Ophthal 1958;59:260-79.

${ }^{5}$ World Health Organisation. Toxoplasmosis. Diagnostic methods. WHO Tech Rep Ser 1969;431:18-9.

${ }^{6}$ Jacobs L, Lunde MN. A hemagglutination test for toxoplasmosis. J Parasit 1957;43:308-14.

- Thorburn H, Williams H. A stable haemagglutinating antigen for detecting toxoplasma antibodies. J Clin
Pathol 1972;25:762-7.

${ }^{8}$ Jennis F. A simplified haemagglutination test for toxoplasmosis using pyruvic aldehyde treated cells. Aust J Exp Biol Med Sci 1966;44:317-22.

${ }^{9}$ Karim KA, Ludlam GB. The relationship and significance of antibody titres as determined by various serological methods in glandular and ocular toxoplasmosis. J Clin Pathol 1975;28:42-9.

${ }^{10}$ Fairchild GA, Greenwald P, Decker HA. An evaluation of the indirect hemagglutination test as a serologic test for toxoplasmosis. Amer J Trop Med Hyg 1967;16:278-83.

${ }^{11}$ Miller LH, Brown HW. The serologic diagnosis of parasitic infections in medical practice. Ann Intern Med 1969;71:983-92.

Requests for reprints to: Dr AH Balfour, Public Health Laboratory, Bridle Path, York Road, Leeds LS15 7TR, UK 